\title{
Child and Adolescent Psychosocial Support Programs Following Natural Disasters—a Scoping Review of Emerging Evidence
}

\author{
Gibbs L. ${ }^{1,2}$ (D) Marinkovic K. ${ }^{1} \cdot$ Nursey J. ${ }^{3}$. Tong L. A. ${ }^{4} \cdot$ Tekin E. $^{5,6,7} \cdot$ Ulubasoglu M. $^{4} \cdot$ Callard N. $^{8} \cdot$ Cowlishaw S. $^{3}$. \\ Cobham V. E. 9,10
}

Accepted: 5 September 2021 / Published online: 15 October 2021

(c) The Author(s) 2021

\begin{abstract}
Purpose of Review This review aimed to identify and describe evidence published in the past 3 years from trials of psychosocial support programs for children and adolescents affected by natural disasters.

Recent Findings Previous reviews have indicated these programs are beneficial overall. Positive impacts were documented in school-based programs conducted by trained teachers and paraprofessionals with stronger effects achieved by more qualified professionals.

Summary The review found supporting evidence for positive impacts of post-disaster psychosocial programs. However, the strength of evidence is limited due to heterogeneity in interventions and evaluations. The stepped care model was found to be useful in differentiating between programs and level of available evidence. Hobfoll's five essential elements of mass trauma intervention provide an additional means of guiding program content and assessments, particularly for universal programs. Identified gaps in evidence included groups likely to be at most risk: preschool children, ethnically diverse groups, those with disability, and social disadvantage. There were promising indications of program benefits for groups with repeated exposure to natural disasters.
\end{abstract}

Keywords Child $\cdot$ Adolescent $\cdot$ Disaster $\cdot$ Mental health $\cdot$ Recovery $\cdot$ Intervention

\section{Introduction}

It is well established that there is an increased risk of mental health problems for both adults and children in the aftermath of a mass trauma event such as a natural disaster [1,2],

This article is part of the Topical Collection on Child and Family Disaster Psychiatry

Gibbs L.

lgibbs@unimelb.edu.au

1 Melbourne School of Population and Global Health, University of Melbourne, Melbourne, VIC, Australia

2 Centre for Disaster Management and Public Safety, University of Melbourne, Melbourne, VIC, Australia

3 Phoenix Australia: Centre for Posttraumatic Mental Health, Melbourne, Australia

4 Department of Economics, Deakin University, Burwood, VIC, Australia

5 School of Public Affairs, American University, Washington, D.C, USA arising from direct exposure to the hazard event as well as the associated losses and disruptions in the following months and years. While many children show signs of initial distress in the aftermath of a natural disaster, most children are expected to recover with the support of family, friends and the school community. A significant minority, however, have lingering mental health problems and are in need of additional support to recover and function normally $[1,3]$.

6 National Bureau of Economic Research (NBER), Cambridge, USA

7 Institute of Labor Economics (IZA), Bonn, Germany

8 Children's Health Queensland Hospital and Health Service, Queensland, Australia

9 School of Psychology, The University of Queensland, Queensland, Australia

10 Children's Health Queensland Child and Youth Mental Health Service, Queensland, Australia 
Pre-disaster experiences of adversity, family circumstances and community levels of disruption are all likely to influence the extent of impact on child health and wellbeing [4]. Even in an event such as the COVID-19 pandemic during which children have been shown to be much less susceptible to the virus than adults, family-level distress and conflicts, overburdened healthcare systems, school closures and social and economic difficulties can still leave children vulnerable. These problems may adversely affect food security, disrupt cognitive and emotional development, impair access to social and medical services and increase the likelihood of exposure to family violence $[5,6]$.

There has been increasing recognition of the need for appropriate disaster recovery support programs for children and adolescents over the past two decades. These programs can be difficult to operationalise in the upheaval of a postdisaster environment. Given the increasing risk of disasters occurring with more frequency, severity and complexity due to climate change, it is imperative to monitor emerging evidence about which programs are likely to provide the most effective support and which program delivery modes are likely to be feasible and appropriate in post-trauma settings.

The Australian and International Guidelines for the Treatment of Acute Stress Disorder and Posttraumatic Stress Disorder recommend a stepped care approach to post-disaster psychosocial recovery for both children and adults [7]. In the post-disaster context, a stepped care model assumes resilience, but offers recovery support at the community level in the first days and weeks after a disaster, followed by increasingly intensive, targeted, transdiagnostic interventions for those demonstrating ongoing distress and/or who are identified as being at risk of developing a mental health disorder. This approach relies on effective screening and triage practices to ensure those at risk are identified and provided access to the appropriate level of care as early as possible [8].

Level 1 in the stepped care approach, identified as universal care, promotes recovery by offering support, education and advice on self-care strategies such as calming techniques and social connectedness. Psychological First Aid (PFA), based on five essential elements of immediate and mid-term mass trauma intervention identified by Hobfoll et al. [9]namely safety, connectedness, self and collective efficacy, calm and hope, is an example of a level 1 universal intervention. There are multiple versions and implementation guides for PFA, including directions written specifically for use with children $[10,11]$.

Level 2 specifies both "selective" and/or "indicated" interventions that are targeted at those exhibiting continued signs of distress or sub-clinical signs of a mental health disorder in the months following the disaster. These early intervention programs usually offer some skills training in adaptive coping aimed at building resilience and reducing the risk of developing a posttraumatic mental health disorder. An example of a level 2 intervention developed by an international panel of trauma experts for use with children, adolescents and adults is Skills for Psychological Recovery (SPR) [12]. Another is Skills for Life Adjustment and Resilience (SOLAR) [13]. Appropriately, trained health care professionals or community support personnel can deliver these interventions at either a primary care or community level.

Level 3 interventions are high-intensity, evidence-based psychological therapies aimed at treating diagnosed posttraumatic mental health disorders and must be delivered by specialist mental health professionals. Interventions with the strongest evidence base are Trauma-Focused Cognitive Behavioural Therapies and can be transdiagnostic in nature or targeting a specific disorder.

While the stepped care approach is widely endorsed by trauma specialists and treatment guidelines internationally, the evidence supporting its effectiveness has been slow to develop, particularly regarding level 1 and 2 and childfocussed interventions. However, recent meta-reviews have identified a range of post-disaster psychological and psychosocial interventions for children and adolescents that demonstrate those receiving interventions fared better than those in control or waitlist groups [14-16]. The strongest evidence available was for eye movement desensitization therapy (EMDR), Exposure and Strict Cognitive Behavioral Therapy (CBT) in level 3 interventions [14]. While pre-post studies present evidence of stronger effects when programs were delivered by qualified professionals, and when delivered to individuals rather than groups, these differences in effect sizes were lower or absent in the controlled studies [15]. A meta-review of level 1, schoolbased programs delivered post disaster and published between 2000 and 2015 [16] showed that "school-based, universal programmes that are conducted by teachers or local paraprofessionals are effective in reducing PTSD symptoms in children and adolescents" (p. 161). This finding of the effectiveness of school-based programs is also supported by a previous meta-analysis of school-based (level 3) treatment programs targeted at reducing symptoms of PTSD arising from exposure to various forms of trauma including disaster [17]. All the reviews used measures of psychological distress or PTSD as the outcome measure regardless of whether the intervention was universal (level 1), targeted (level 2) or treatment (level 3). Arguably, measures of PTSD symptoms or any other diagnosable mental health disorder are not appropriate for a level 1 intervention given those interventions do not target specific disorders. Even if used as a screening tool, students with sub-clinical symptoms should be directed to a level 2 intervention and those with more severe symptoms 
to a level 3 intervention. A common recommendation was to conduct further studies with larger samples. Brown and colleagues [15] suggested that the evidence supported a stepped care approach that provides individual treatments for those with high need and a small number of group treatment sessions for those with lesser needs.

The challenges associated with conducting clinical trials and evaluating the effectiveness of interventions in post-disaster environments are well-known, with multiple factors contributing to the complexity, not least of which is the heterogeneity of program models offered and a lack of identified consistent outcomes and goals [18, 19]. Shultz and Forbes (18, p. 8) outline several questions and processes that might be used as a framework to guide evaluation of PFA. At a minimum, they suggest that "The "five essential elements" identified by Hobfoll and colleagues (safety, calming, connectedness, self-efficacy and hope) might be considered the best "standard" available for assessing the coverage of various PFA frameworks." These elements were developed through expert consensus to guide intervention and prevention efforts following mass trauma events. They were developed in 2007 by extrapolating from related fields of research in the absence of direct evidence at the time. Using them now to review emerging evidence provides the dual benefit of providing a structure for differentiating between available interventions, while also building the evidence for each of the principles.

The goal of this scoping review is to identify any emerging psychosocial interventions and/or new evidence regarding existing disaster recovery programs for children and adolescents that would help inform best practice. The review employs the stepped care model as a structure for differentiating the intervention studies and the presentation of findings.

\section{Methods}

This review was conducted using a scoping review approach informed by Arksey and O'Malley [20]. This approach was consistent with the review's aim to explore recent trends and developments across a wide range of interventions that were designed and assessed based on an array of theoretical and methodological frameworks.

The final search was conducted on 18 May 2021 across the following databases: Cochrane Library, EMBASE, Family \& Society Studies Worldwide, Global Health, Medline, PILOTS (Published International Literature on Traumatic Stress), PsycINFO, Scopus, SocINDEX, and Web of Science and article reference lists. In keeping with the journal focus, the review scope was studies published in the last 3 years.
Inclusion criteria are articles that (a) are peer-reviewed primary research or reviews of primary research, (b) are published in English, (c) are published between 1 January 2018 and 18 May 2021, (d) assess interventions implemented in the aftermath of a natural ${ }^{1}$ disaster, (e) target interventions focusing on child mental health (understanding children as all people under 18 years old).

The review data were categorised according to the stepped care model and the literature on the key elements of interventions for disaster-affected communities. Two team members (KM and LT) developed the evidence table with six test articles. They then independently extracted information from all included articles based on the following categories:

- Study details (reference, organisations involved, name of program/intervention, country/region, type of disaster)

- Level of intervention in the stepped care model

- Elements of interventions (program features, participants and scale, program modules and modality, delivery mode, provider credentials, costs, level of evidence for the program and barriers).

- Alignment of intervention with one or more of the five essential elements of recovery-i.e. safety, calming, connectedness, efficacy and hope.

- Discrepancies in study selection and data extraction were resolved in collaboration with other members of the research team (LG and JN). The final step was to collate, summarize and synthesize the extracted information, based on the following guiding questions:

- When and where were the interventions implemented?

- What type of interventions were delivered?

- How did the interventions align with the five essential elements of disaster recovery?

- How were the interventions delivered?

- Who received the interventions?

- What intervention evaluation study designs were used?

- What were the outcomes and impact of the interventions?

\section{Results}

A total of 18 studies were identified, including 13 primary research articles and 5 literature reviews (see Fig. 1).

The 5 literature reviews aimed to compare the effects of different interventions on PTSD, depression, and anxiety $[21,22 \bullet, 23,24 \bullet \bullet]$, and identify the factors that influence

\footnotetext{
${ }^{1}$ We acknowledge the term "natural disasters" is contested because of the human/social influences on these events but use it here as a useful distinction from disasters arising from acts of violence such as terrorism and war.
} 
Fig. 1 Flow chart for the process of study selection

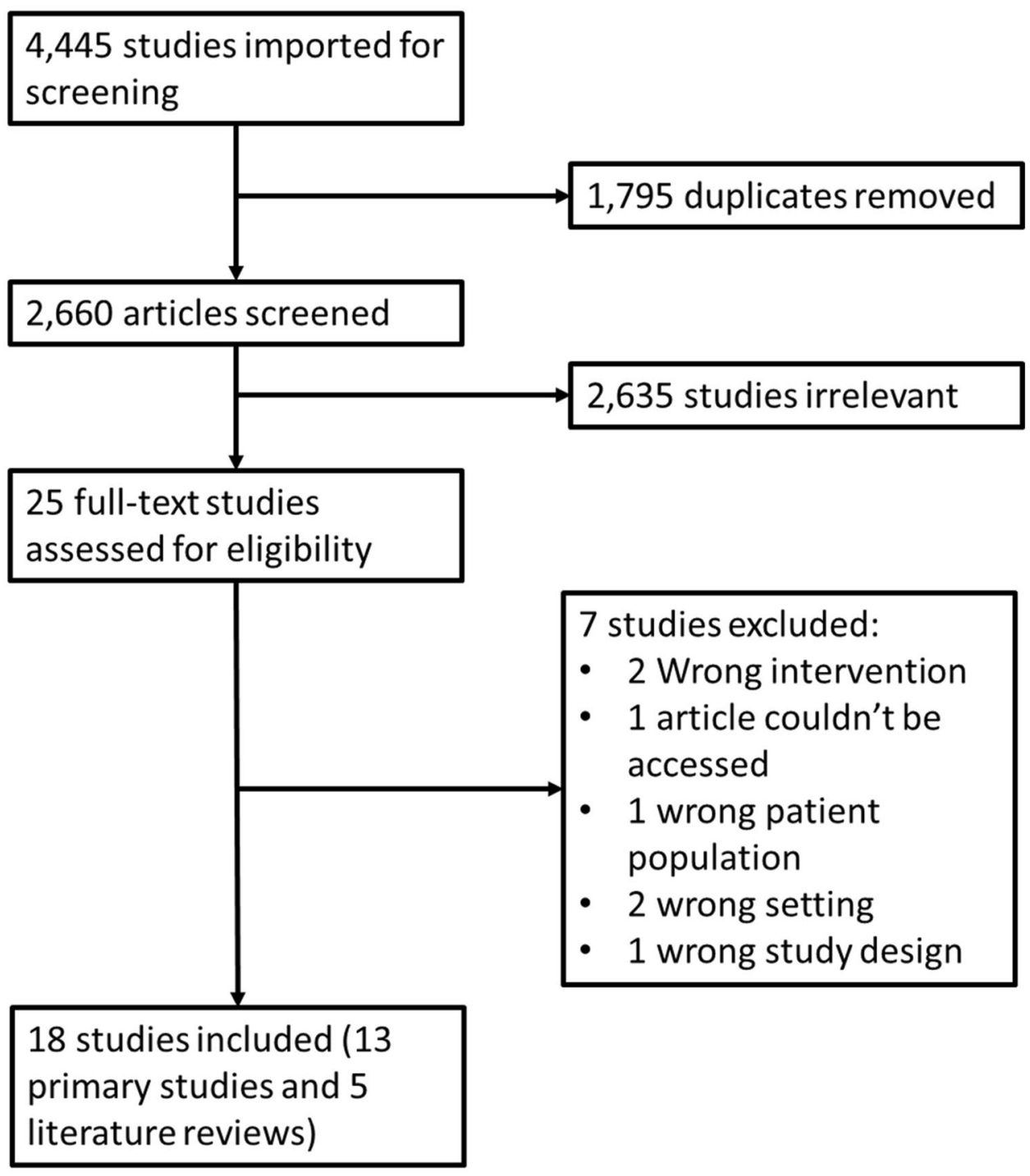

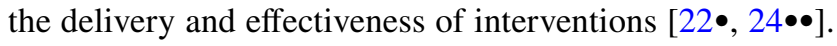
In terms of the nature of the event, one review [21] focused on different types of natural disasters, while the rest explored interventions delivered in a wider range of potentially trau-

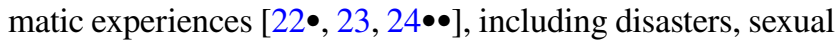
and physical abuse, war, terrorism and other humanitarian crisis. Additionally, one review [25] focused on identifying interventions for children and families in the context of COVID-19 and comparable outbreaks. No further description of the reviews will be provided in these results because they assessed studies that were either conducted prior to 2018 or were captured in this scoping review. However, the literature reviews will be referred to throughout the discussion to indicate similarities and differences in the findings that have emerged from the more recent primary research studies.

The 13 primary research studies corresponded to 13 different interventions and will now be described in detail in the results below.

\section{When and Where Were the Interventions Implemented?}

The studies identified by this review were carried out in different countries across Asia [26, 27•, 28, 29•, 30, 31], the Americas (four, with two interventions from the USA [32, 33] and two from Canada [34, 35], Europe [36•], Africa [37] and Oceania [38]).

Table 1 summarizes the main characteristics of the interventions identified in this review. The interventions were carried out between 2006 and 2020, although four studies did not report when the post-disaster intervention occurred (and how long after the disaster) or its duration. Four interventions were implemented while the COVID-19 pandemic was happening [30, 32, 34, 35], two interventions were carried out within a few months of a disaster [29•, 37] and three interventions were implemented 1 year after the disaster or shortly after the first anniversary [26, 33, 38]. 


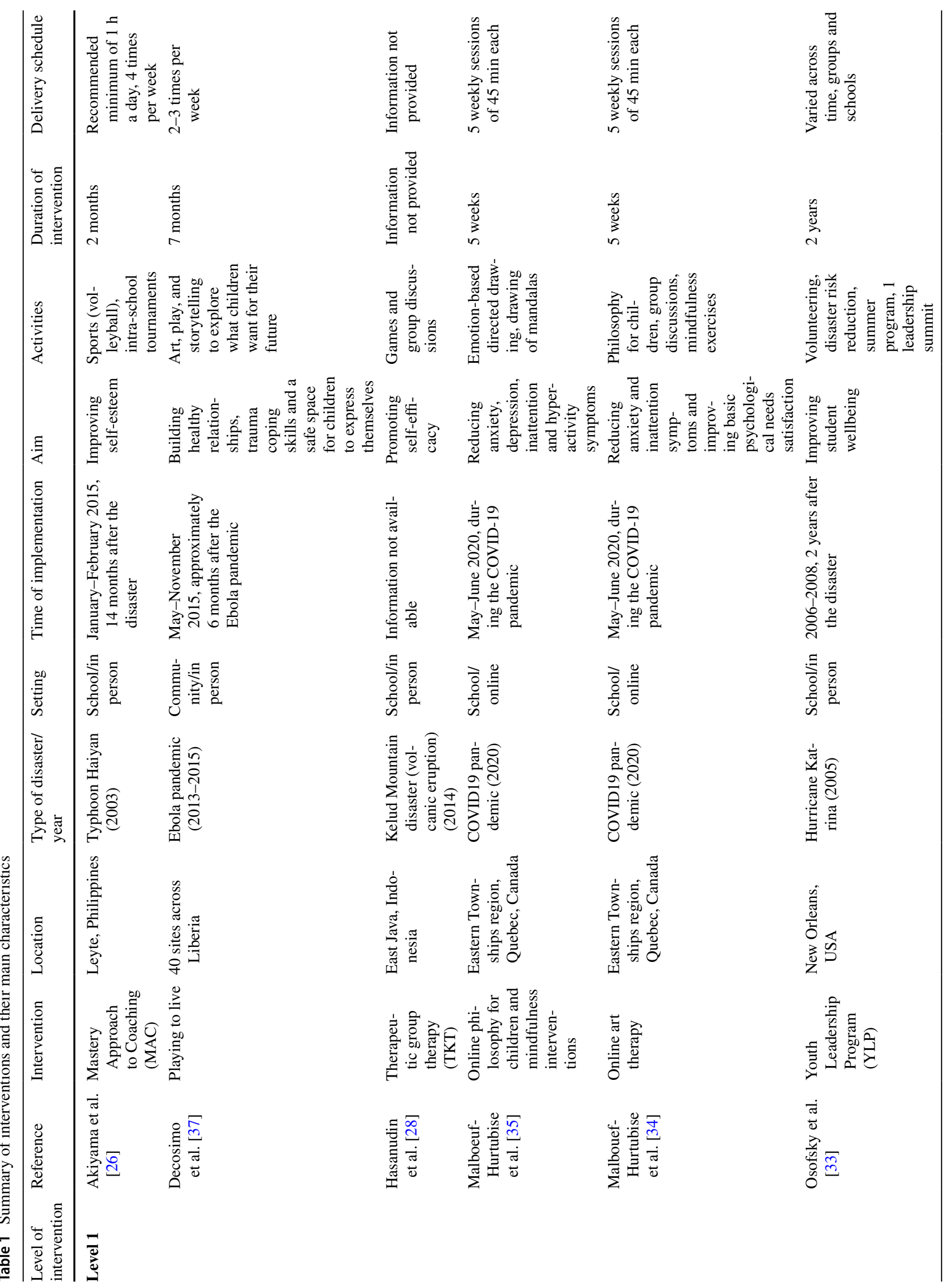




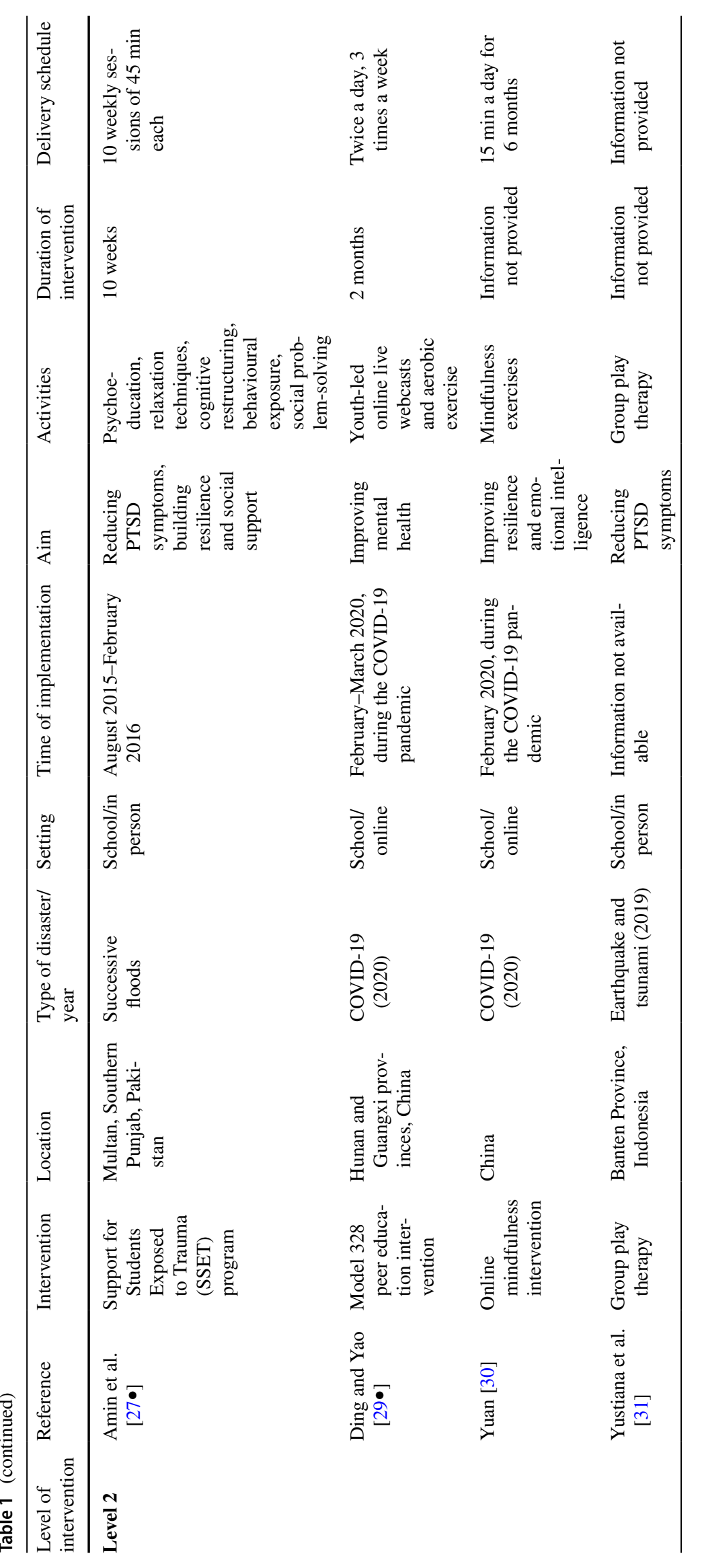




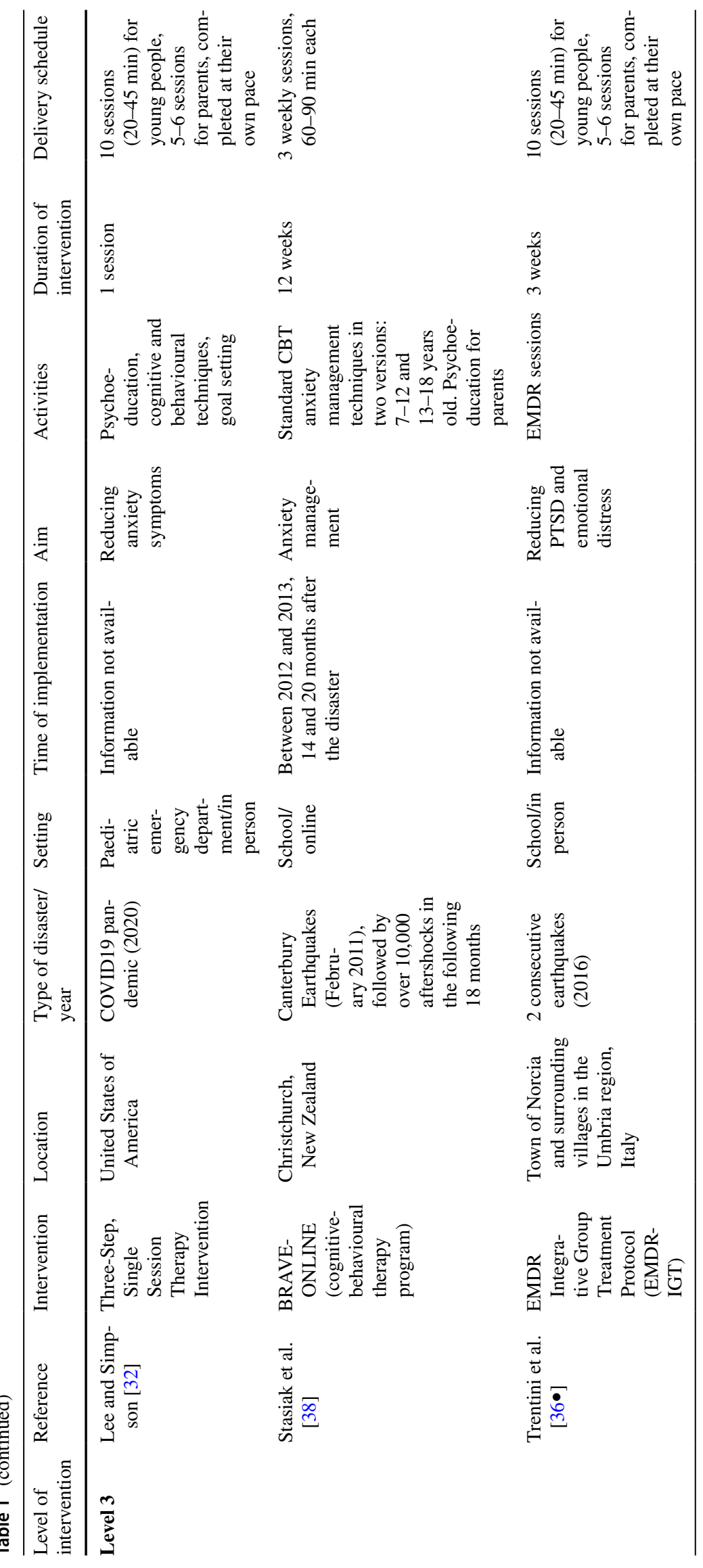


Fig. 2 Intervention alignment with the five essential elements of disaster recovery

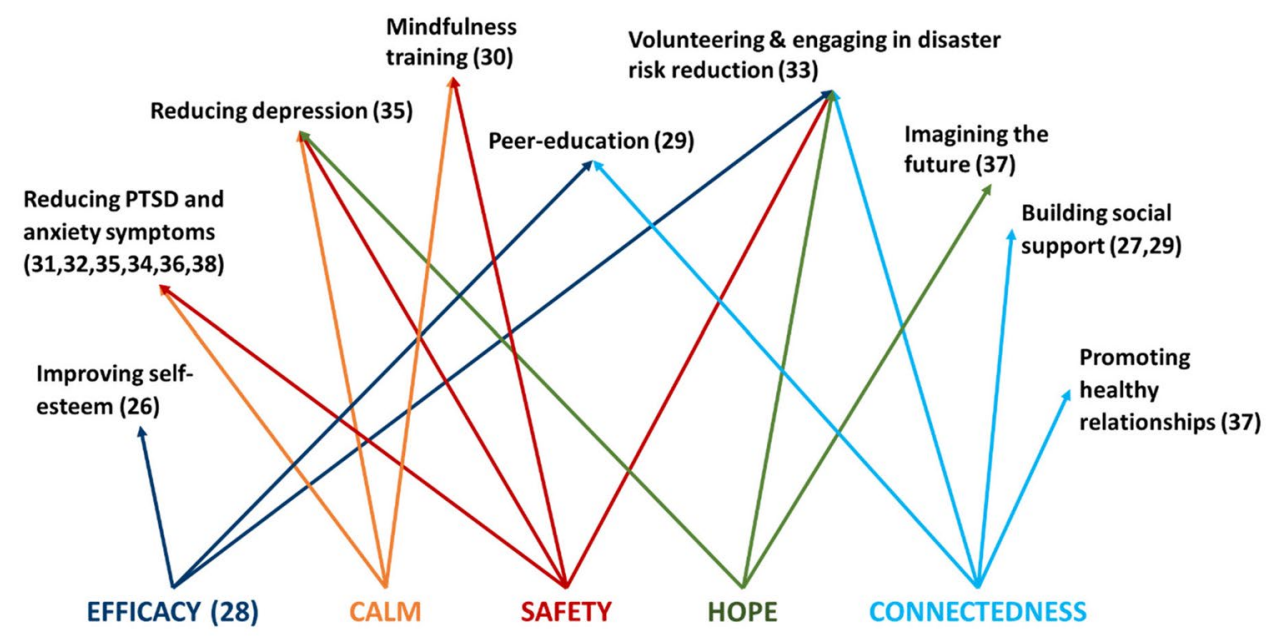

Interventions for child mental health were performed in response to pandemics-mostly COVID-19 [29•, 30, 32, 34, $35,37]$, earthquakes [31, 36•, 38], floods [27•], hurricanes [33], tsunamis [31], typhoons [26] and volcanic eruptions [28]. Ten out of thirteen interventions were carried out in school contexts [26, 27•, 28, 29•, 30, 31, 33-35, 36•]. Eight interventions were delivered face to face [26, 27•, 28, 31-33, 36•, 37], while the rest were online [29•, 30, 34, 35, 38]. Almost all the online interventions [29•, 30, 34, 35] were designed in response to the challenges of accessing children during the COVID-19 pandemic in 2019-2020, with one exception that was delivered after an earthquake [38]. This was the only study to report problems caused by frequent technological glitches and high attrition rates.

Most interventions were delivered by clinically trained personnel and mental health professionals [27•, 31-33, 36•, 38 ], or by researchers with a background in mental health [28, 29•, 34, 35]. Four studies reported that interventions were delivered by or with the support of local teachers [26, 30,33 ] or community workers [37], but did not provide details on whether these deliverers had also been affected by the disaster themselves.

\section{What Type of Interventions Were Implemented?}

The interventions identified in this review were based on a diverse set of frameworks, drawing mostly from therapeutic approaches like cognitive-behavioural therapy [27•, 32, 38], EMDR [36•], art therapy [35, 37], yoga therapy, play therapy, child development [37] and group therapy [28, 31], but also from mindfulness [30, 34], philosophy for children [34], health promotion and education [29•, 33], communitybased interventions [33], coaching [26] and peer education [29•] (see Appendix 1).

Table 1 shows that the most common aim for interventions was to reduce symptoms of psychological distress (e.g. anxiety, mood, inattention and hyperactivity) and improve coping skills [27•, 31, 32, 34, 35, 36•, 37]. Other interventions aimed to promote resilience and emotional intelligence [27•, 28, 30], social support [27•, 29•], self-expression [37], self-efficacy [28] and self-esteem [26]. Only one intervention explicitly aimed to engage children and youth in disaster recovery activities [33].

Six interventions corresponded to level 1 in the stepped care model [26, 28, 33-35, 37], four interventions were classified as level 2 [27•, 29•, 30, 31] and three interventions corresponded to level 3 [32, 36•, 38]. Most interventions $(N=10)$ were delivered in groups [26, 27•, 28, 29•, $31,33-35,36 \bullet, 37]$ and three were delivered to individual children [30, 32, 38]. The activities used to promote mental health varied greatly across interventions. They included sports [26, 29•], psychoeducation [27•, 32, 38], mindfulness, meditation or relaxation techniques [27•, 30, 34], cognitive and behavioural restructuring techniques [27•, 32, 38], art [35, 37], play [31, 37], group therapy techniques [28], philosophy discussions [34], volunteering in the community [33], engaging in disaster recovery [33], and EMDR group sessions [36•]. Most interventions had fixed contents, meaning they were designed to deliver standardised content in a standardised format [26, 27•, 28, 29•, 30, 34, $35,37,38$, although researchers in one study reported that the frequency of sessions could not be kept the same across sites [26]. In two other studies, researchers reported that the intervention was outlined in broad terms and then tailored to the needs of the community [33] or individual patient being targeted [36•].

\section{How Did the Interventions Align with the Five Essential Elements of Disaster Recovery?}

Figure 2 shows how the different interventions aligned with the five essential elements of disaster recovery (safety, calm, 
connectedness, efficacy, hope) [9]. Only one intervention [28] explicitly stated an intent to address one of the five elements: self-efficacy. However, for the rest of the interventions, it was possible to link their objectives with different elements.

From this perspective, most interventions served to promote a sense of safety $(N=9)$, followed by calm $(N=8)$, connectedness $(N=5)$, efficacy $(N=4)$ and hope $(N=3)$. All the interventions that addressed connectedness [27•, $29 \bullet, 33,37]$ and hope $[33,34,37]$ were classified as either level 1 or 2 interventions. Some interventions also included additional components such as physical health aspects (sleep and exercise)

\section{How Were the Interventions Delivered?}

The duration of interventions ranged from a single session to 2 years, with the majority lasting about two months (Table 1). The scale of interventions varied from a sub-section of a school [34, 35], to school-wide [26, 33], to different locations within a city [38], region or nation [37] (Appendix $1)$.

Most interventions involved multiple sessions at regular intervals, that lasted between 45 and $60 \mathrm{~min}$ (Table 1). Most interventions had weekly sessions [27•, 33-35, 36•], and three had more than one session per week (between 2 and 4 ) $[26,29 \bullet, 37]$. Exceptions included, a single-session intervention [32], a 10-session online self-paced intervention [38] and brief daily mindfulness exercises [30].

\section{Who Received the Interventions?}

All the interventions identified in this review worked directly with children to support their mental health and almost all of them $(N=10)$ were delivered to groups of children [26, 27•, 28, 29•, 31, 33-35, 36• 37] (Appendix 2). Some targeted children between ages 7 and 13 [27•,34,35]; others worked with different ages and stages [31, 33, 37] but did not report how they tailored activities to the different ages, except one intervention [38] which reported two different modes of delivery: for ages 7-12 years and for 13-18 years. Three studies $[28,31,36 \bullet]$ did not report the age of the children receiving the intervention. No interventions were specially developed for preschool children. Five interventions also offered support and information to parents/caregivers [27•, $32,37,38]$ or teachers [31].

\section{What Intervention Evaluation Study Designs Were Used?}

A range of study designs were used to assess the impact of the interventions (see Table 2). The randomised experimental trials and randomised cluster trials provide the greatest strength of evidence in terms of study design [27•, 29•, 34, 35] but sample sizes were small (ranging from 22 to 141 participants). Quasi-experimental trials were also common $[26,28,30,31,33]$ (where participants are not randomly assigned to the intervention or the control group). Importantly, only one study [33] carried out a longitudinal analysis of the impacts of an intervention 2 years after the disaster.

Table 2 also shows that the sample size varied greatly across all the studies, from 1 to 332 children. Small sample size was a common limitation reported by studies [26, 34, 35]. Most studies reported the age and gender of children and aimed to achieve a balance between female and male participants. Only three studies reported on the involvement of children from minority groups $[27 \bullet, 33,38]$. None of the studies reported involvement of children with disabilities. Only two studies $[27 \bullet, 38]$ reported the socioeconomic status (SES) of their participants but did not use that data to examine the effect of SES or to adjust for SES in assessment of intervention impacts.

Table 2 also shows the interventions according to their expected outcomes and measures, demonstrating the wide range of standardised measures used to evaluate outcomes related to different aspects of children's mental health, behaviour and wellbeing. Only one study [33] incorporated a measure of children's level of disaster exposure before receiving the intervention.

\section{What Were the Outcomes and Impact of the Interventions?}

Considering the study limitations in strength of evidence as described in the previous section, the studies considered in this review suggested an overall positive impact of the different interventions in terms of reducing PTSD symptoms, depression, anxiety, sleep problems and promoting resilience, perceived social support and self-efficacy [26, $27 \bullet, 28,29 \bullet, 31-35,36 \bullet, 37]$.

However, findings were often mixed in terms of which aspects of the interventions were most effective and which sub-groups benefitted the most. One study reported that the intervention using group play therapy helped decrease PTSD symptoms including intrusions, avoidance, negative alterations in cognitions and mood, and alterations in arousal and reactivity [31], and another study [36•] found that EMDR group interventions were more effective in females and older children. While most level 2 and 3 studies included a measure of PTSD symptoms, almost all the PTSD and other outcomes were determined using self-report measures. Only two level 3 studies $[32,38]$ determined anxiety symptoms through diagnosis from a specialized clinician.

In relation to interventions that also had a component to support teachers [31] or parents/caregivers [27•, 32, 38], only one study [31] assessed the impact of the intervention 


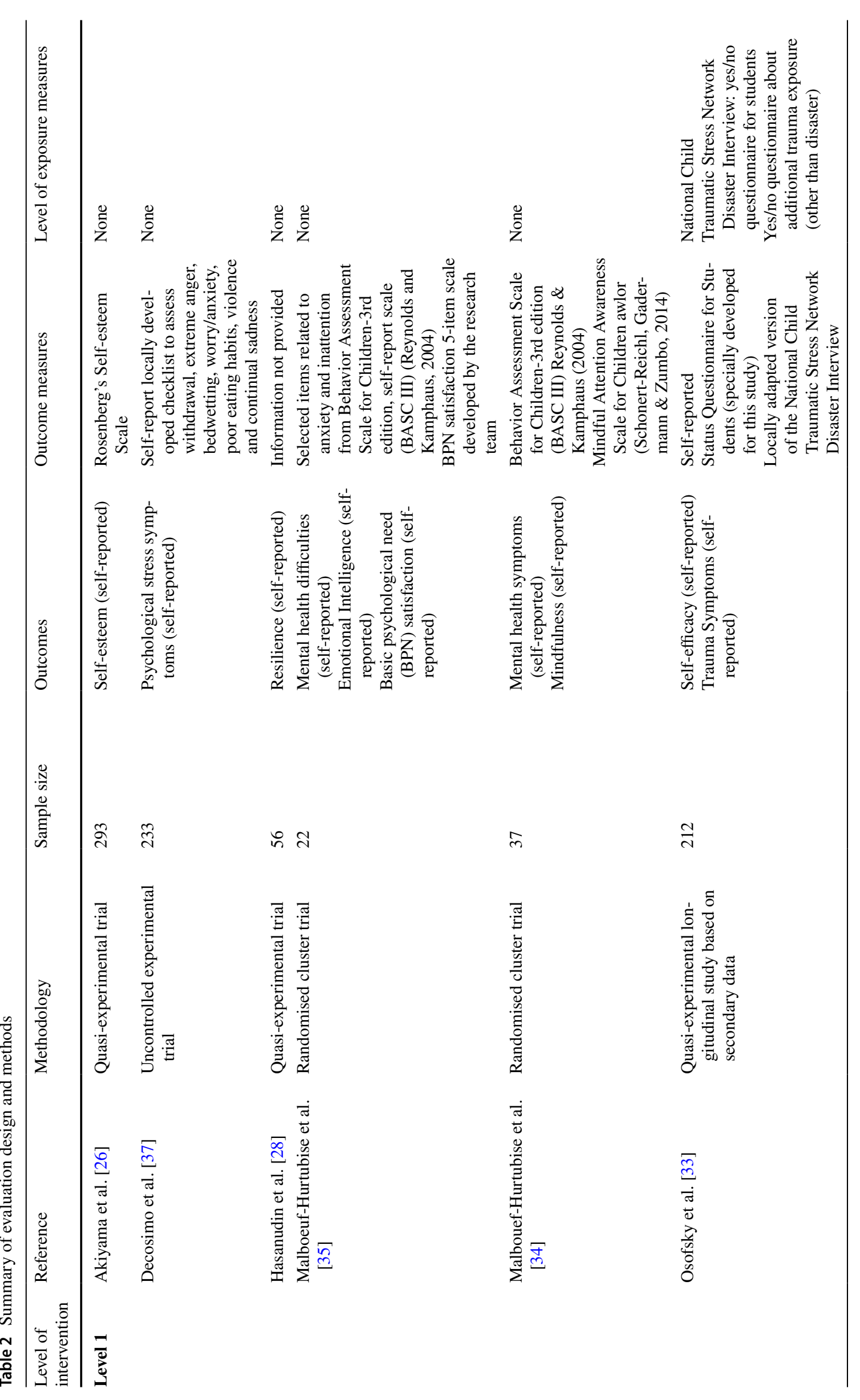




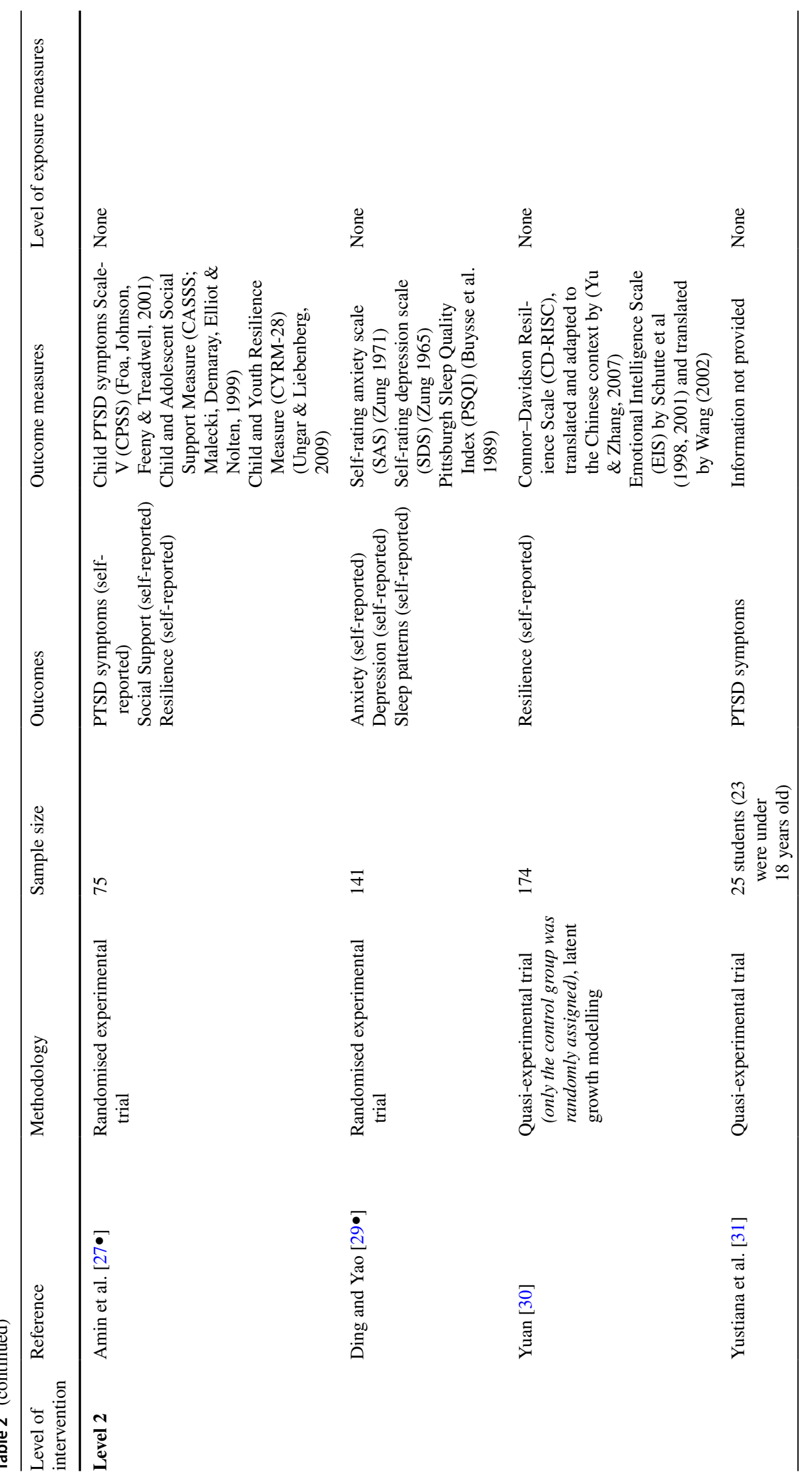




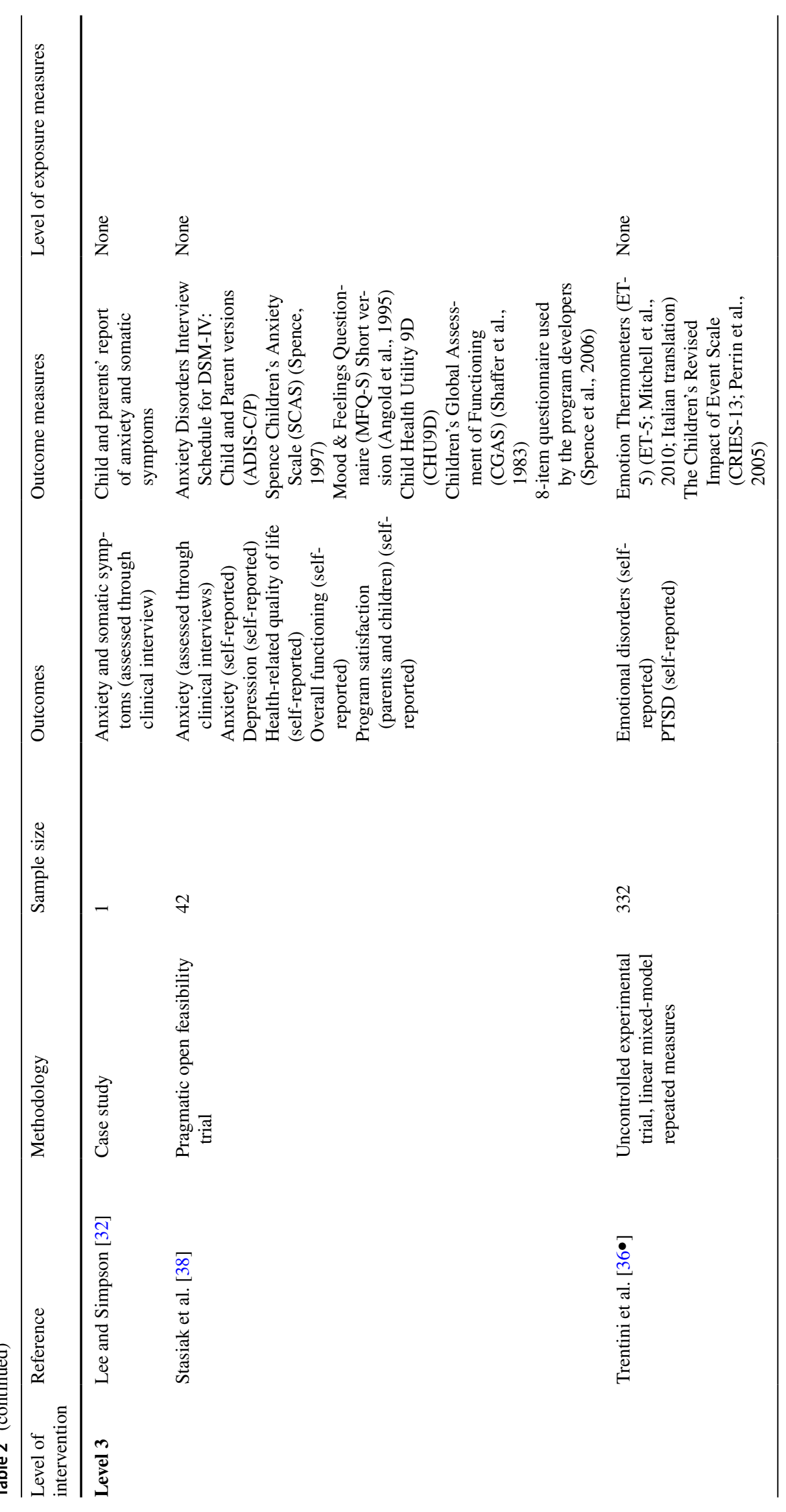


on adults' mental health. However, this evaluation measured the impact of the intervention on teachers and students together, so it is not possible to make any conclusions about the intervention's effects on adults.

In addition to limitations already noted in relation to sample size and lack of diversity, study authors reported participant attrition [37], lack of follow up over time [34, 35], variations in the implementation of interventions across different study sites [26], and not assessing other potential sources of support that may have influenced the outcomes of an intervention [30]. Several studies reported not using randomised control groups [33-35, 36•, 37, 38] because of ethical concerns. Limitations of instruments used for measuring intervention effects included uncertainty about reliability of translated questionnaires [26, 28], challenges assessing complex concepts with multiple dimensions like resilience [33] and bias in clinical assessments [38]. Details on costeffectiveness, inclusiveness, risk management strategies (e.g. mitigating risk of re-traumatisation) and implementation processes were also commonly missing from evaluation reports (see Appendix 3).

\section{Discussion}

This scoping review aimed to identify recent intervention and evaluation trials of post-disaster psychosocial programs for children and adolescents after disasters. The findings revealed studies conducted across five continents, following a wide range of types of natural disasters including major weather events, floods, volcano, pandemic and tsunami. They were delivered to different age groups, with schools being the most common setting for delivery, building on previous reviews of school-based programs [16, 17]. Unfortunately, it appears that the unique mental health needs of children in their preschool years continue to be overlooked [39].

Presenting the review findings within a stepped care framework in which universal interventions were allocated to level 1, targeted interventions to level 2 and treatment interventions to level 3, provided a useful means of differentiating the evidence. More of the recent studies of mental health interventions for children after disasters corresponded to level 1 interventions $(N=6)$ with slightly less defined as level $2(N=4)$ or level $3(N=3)$. This may manifest a shift towards mental health promotion through communitybased interventions, consistent with evidence showing that, after disasters, most children will show signs of resilience, and a few will develop more severe symptoms that require more specialized treatment $[1,3,15]$. While the evidence is building across each level of the stepped care approach, the strength of evidence is still limited due to considerable heterogeneity in intervention strategies, evaluation study design, timeframes and measures used [15]. Study limitations also included challenges achieving adequate sample sizes, participant attrition, lack of diversity, technological problems in online delivery, measurement challenges and lack of differentiation based on socioeconomic status. A meta-analysis identified by this review [24••] concluded that more research is needed on the influence of socioeconomic factors on the effectiveness of mental health interventions for children.

All the interventions were assessed in terms of their outcomes and impacts, and most included some sort of control or comparison group. The overall findings show positive program impacts on the mental health and wellbeing of the children and adolescent participants, consistent with previous reviews $[14,15,17]$. The literature reviews that aimed to compare the impact of level 3 interventions found that CBT was the most beneficial intervention for children [21, 22•, 23], followed by EMDR [22•, 23]. In terms of the factors influencing the impact of interventions, in their metaanalysis, Pfefferbaum and colleagues [24••] investigated a range of factors that might potentially influence treatment effectiveness and found that interventions that had significant effects on depression tended to be carried out in highincome countries and had more than eight sessions and interventions that were non-trauma focused.. Only non-traumafocused interventions had a significant effect on anxiety symptoms. They noted however that the reliability of these findings was undermined to some extent by the heterogeneity of the studies and a lack of specific information provided about the interventions used.

The evidence on the negative impact of disasters on mental health shows that these effects can be long-lasting $[1,3]$. More longitudinal studies are needed to assess the impact of interventions in the mid to long term. Intervention trials conducted with children and adolescents who have experienced multiple disasters are also increasingly important as the onset of climate change increases the likelihood of exposure to more frequent, more severe and more complex disaster scenarios [40]. In this review, most studies involved population groups exposed to a single major disaster event but importantly two of the studies were conducted with children who experienced repeat exposures to the same type of hazard [36•, 38] and one intervention involved students who experienced two different types of disasters-earthquake and tsunami [31], with positive outcomes. It is not clear in the Amin et al. report [27•] if the children and schools included in the study had repeated exposure to the floods or not. Lewey et al. [22•] in their review of EMDR and TF-CBT trials for children and adolescents found no significant differences in the effect sizes of studies for those with exposure to either single or mixed trauma type (chronic or repeated events).

The COVID-19 pandemic is reshaping mental health interventions for children after disasters, with new advances 
in use of digital technology to teach children and developing telehealth interventions. This was reflected in this review which identified four interventions conducted online during the COVID-19 pandemic. An additional equity consideration for these interventions is the level of access that families have to digital devices and internet connection and provides an example of how local considerations can be important in shaping psychosocial interventions and evaluation of impacts. The importance of stakeholder input into disaster preparedness and recovery initiatives is enshrined in the Sendai Framework for Disaster Risk Reduction [41]. While standardised programs may be more easily replicated across large geographic areas with multiple locations, they can have the disadvantage of not adapting to local and individual resources and needs. Community involvement in intervention planning was a feature of one level 1 study [33] but most interventions were led by organizations from outside the community and the vast majority of the interventions had standardised content rather than tailoring them to different locations or individual children. One study demonstrated capacity to localise to a certain extent by engaging with local community to adapt the intervention to local languages in a level 2 intervention [27•] and another adjusted the treatment protocol to patients' symptoms in a level 3 intervention [36•]. Only one of the interventions in this review explicitly engaged children and youth in disaster recovery activities [33]. Involvement in disaster recovery planning and activities can be beneficial for young people [3] and this could have a positive influence on self-efficacy, one of the five essential elements of intervention following a mass trauma intervention [9]. Self-efficacy was explicitly addressed by only one of the interventions [28] and none of the other 5 essential elements were named by any of the interventions. However, we propose that each intervention's aims did align with at least one of the elements-calm, safety, connectedness, efficacy and hope. The most common aim was reducing PTSD, anxiety and depression symptoms, arguably a means of promoting a sense of calm and safety. Conversely, promoting hope and connectedness were the two elements that were addressed by the smallest number of interventions. All of the interventions addressing hope were level $1[33,35$, 37] and those addressing connectedness were level 2 [27•, 29•] interventions. It may be helpful for future interventions to consider these elements in planning both intervention and evaluation components.

\section{Conclusions}

This scoping review contributes to the growing understanding of the contribution of psychosocial programs to child and adolescent recovery following exposure to natural disasters. Most importantly, it shows that positive impacts are being achieved across a range of programs, delivery modes and settings. Further studies are needed to confirm the findings because there are still a number of limitations to the evidence, not surprisingly given the complexity of post-trauma mental health needs and the disrupted context of post-disaster environments. Structuring the evidence according to a stepped care model provides a useful means of aligning the available evidence with recommended approaches. Similarly, Hobfoll et al.'s [9] nominated five essential elements for intervention following mass trauma, provide a guide for both intervention aims and assessment that is consistent with programs currently being delivered, if not explicitly stated. The most common focus across the interventions, and thus the developing evidence, was promotion of a sense of calm and safety. Unfortunately, current gaps in the evidence relate to potentially the most vulnerable of groups-preschool children, culturally and linguistically diverse groups, children and adolescents with disabilities, and socioeconomic disadvantage. This highlights future research priorities, as well as the need to build further understanding of programs that are feasible and effective in complex, multi-exposure disaster settings.

\section{Appendix}

\section{Appendix 1 Interventions according to whether developers and deliverers belonged to the disaster-affected community, scale of the intervention, framework and fixed vs tailored contents}




\begin{tabular}{|c|c|c|c|c|c|c|}
\hline $\begin{array}{l}\text { Level of } \\
\text { intervention }\end{array}$ & Reference & $\begin{array}{l}\text { Where was the intervention } \\
\text { designed? }\end{array}$ & $\begin{array}{l}\text { Who delivered the intervention? } \\
\text { Were program deliverers local } \\
\text { or external to the community? }\end{array}$ & $\begin{array}{l}\text { Scale of the } \\
\text { intervention }\end{array}$ & Framework & $\begin{array}{l}\text { Fixed vs tailored } \\
\text { contents }\end{array}$ \\
\hline \multirow[t]{6}{*}{ Level 1} & Akiyama et al. [26] & Outside the country & Local teachers & $\begin{array}{l}\text { School-wide } \\
\text { (across } 1 \\
\text { school) }\end{array}$ & $\begin{array}{l}\text { The Mastery Approach } \\
\text { to Coaching (MAC), } \\
\text { based on goal orienta- } \\
\text { tion theory }\end{array}$ & Fixed \\
\hline & Decosimo et al. [37] & $\begin{array}{l}\text { Same country where the inter- } \\
\text { vention was implemented }\end{array}$ & $\begin{array}{l}\text { Local psychosocial workers and } \\
\text { community members }\end{array}$ & $\begin{array}{l}\text { Nation-wide, } 40 \\
\text { sites }\end{array}$ & $\begin{array}{l}\text { Art therapy, yoga } \\
\text { therapy, play therapy, } \\
\text { child development }\end{array}$ & Fixed \\
\hline & Hasanudin et al. [28] & Outside the country & $\begin{array}{l}\text { Researchers from the same coun- } \\
\text { try, but it was not mentioned if } \\
\text { they belonged to the community }\end{array}$ & $\begin{array}{l}\text { Information not } \\
\text { provided }\end{array}$ & $\begin{array}{l}\text { Therapeutic Group } \\
\text { Therapy }\end{array}$ & Fixed \\
\hline & $\begin{array}{l}\text { Malboeuf-Hurtubise et al. } \\
\text { [35] }\end{array}$ & $\begin{array}{l}\text { Same country where the inter- } \\
\text { vention was implemented }\end{array}$ & $\begin{array}{l}\text { Undergraduate psychology } \\
\text { students under the supervi- } \\
\text { sion of a clinician, it was not } \\
\text { mentioned if they belonged to } \\
\text { the community }\end{array}$ & $\begin{array}{l}1 \text { classroom in } \\
\text { an elementary } \\
\text { school }\end{array}$ & $\begin{array}{l}\text { Art therapy and mind- } \\
\text { fulness }\end{array}$ & Fixed \\
\hline & $\begin{array}{l}\text { Malbouef-Hurtubise et al. } \\
\text { [34] }\end{array}$ & $\begin{array}{l}\text { Same country where the inter- } \\
\text { vention was implemented }\end{array}$ & $\begin{array}{l}\text { Undergraduate psychology } \\
\text { students under the supervi- } \\
\text { sion of a clinician, it was not } \\
\text { mentioned if they belonged to } \\
\text { the community }\end{array}$ & $\begin{array}{l}1 \text { classroom in } \\
\text { an elementary } \\
\text { school }\end{array}$ & $\begin{array}{l}\text { Philosophy for } \\
\text { children (P4C) and } \\
\text { mindfulness-based } \\
\text { interventions (MBIs) }\end{array}$ & Fixed \\
\hline & Osofsky et al. [33] & $\begin{array}{l}\text { Same community where the } \\
\text { intervention was imple- } \\
\text { mented }\end{array}$ & $\begin{array}{l}\text { Local teachers and mental health } \\
\text { professionals }\end{array}$ & School-wide & $\begin{array}{l}\text { Community-based } \\
\text { and mental health } \\
\text { approaches to stress } \\
\text { reduction and self- } \\
\text { awareness }\end{array}$ & Tailored to the community \\
\hline \multirow[t]{4}{*}{ Level 2} & Amin et al. $[27 \bullet]$ & Outside the country & $\begin{array}{l}\text { External clinicians with local non- } \\
\text { clinical staff }\end{array}$ & $\begin{array}{l}\text { Regional (across } \\
5 \text { elementary } \\
\text { public schools } \\
\text { in three } \\
\text { rural union } \\
\text { councils) }\end{array}$ & $\begin{array}{l}\text { Cognitive-Behavioural } \\
\text { Intervention for } \\
\text { Trauma in Schools }\end{array}$ & $\begin{array}{l}\text { Fixed, but tailored to the } \\
\text { local languages }\end{array}$ \\
\hline & Ding and Yao [29•] & $\begin{array}{l}\text { Same country where the inter- } \\
\text { vention was implemented }\end{array}$ & $\begin{array}{l}\text { Researchers from the same coun- } \\
\text { try, but it was not mentioned if } \\
\text { they belonged to the community }\end{array}$ & $\begin{array}{l}\text { Across } 2 \\
\text { regions in } \\
\text { China }\end{array}$ & $\begin{array}{l}\text { Health education, } \\
\text { evidence on the } \\
\text { effects of exercise on } \\
\text { physical and mental } \\
\text { health }\end{array}$ & Fixed \\
\hline & Yuan [30] & Information not provided & Local teachers & $\begin{array}{l}\text { Information not } \\
\text { provided }\end{array}$ & Mindfulness & Fixed \\
\hline & Yustiana et al. [31] & Information not provided & $\begin{array}{l}\text { One researcher from the same } \\
\text { country where the intervention } \\
\text { was delivered }\end{array}$ & $\begin{array}{l}\text { Information not } \\
\text { provided }\end{array}$ & Group play therapy & Information not provided \\
\hline \multirow[t]{3}{*}{ Level 3} & Lee and Simpson [32] & $\begin{array}{l}\text { Same country where the inter- } \\
\text { vention was implemented }\end{array}$ & $\begin{array}{l}\text { Clinicians from the Paediatric } \\
\text { Emergency Department where } \\
\text { the intervention was delivered }\end{array}$ & $\begin{array}{c}\text { One Paediatric } \\
\text { Emergency } \\
\text { Department }\end{array}$ & $\begin{array}{l}\text { Cognitive-behavioural } \\
\text { therapy }\end{array}$ & Fixed \\
\hline & Stasiak et al. [38] & Outside the country & $\begin{array}{l}\text { The online intervention was } \\
\text { implemented with minimal } \\
\text { involvement from clinical and } \\
\text { occupational therapists }\end{array}$ & City-wide & $\begin{array}{l}\text { Cognitive-behavioural } \\
\text { therapy }\end{array}$ & Fixed \\
\hline & Trentini et al. $[36 \bullet]$ & Outside the country & $\begin{array}{l}\text { EMDR therapists working in } \\
\text { pairs, who were from the same } \\
\text { country or region where the } \\
\text { intervention was implemented }\end{array}$ & Regional & $\begin{array}{l}\text { EMDR-IGTP, based on } \\
\text { the Standard EMDR } \\
\text { Protocol with ele- } \\
\text { ments from group and } \\
\text { art therapy }\end{array}$ & $\begin{array}{l}\text { Fixed, but the protocol } \\
\text { was adjusted to each } \\
\text { patient's symptoms, } \\
\text { stage of development } \\
\text { and response to treat- } \\
\text { ment }\end{array}$ \\
\hline
\end{tabular}




\section{Appendix 2 Recipients of the interventions identified in this review}

\begin{tabular}{|c|c|c|c|c|c|}
\hline $\begin{array}{l}\text { Level of } \\
\text { intervention }\end{array}$ & Reference & $\begin{array}{l}\text { Age of children } \\
\text { who received the } \\
\text { intervention }\end{array}$ & $\begin{array}{l}\text { Was the intervention } \\
\text { delivered individually } \\
\text { or in groups? }\end{array}$ & $\begin{array}{l}\text { Did children receive the } \\
\text { intervention directly, or } \\
\text { indirectly through training } \\
\text { of teachers or caregivers? }\end{array}$ & $\begin{array}{l}\text { Did the intervention } \\
\text { include a component } \\
\text { to support adults? }\end{array}$ \\
\hline \multirow[t]{6}{*}{ Level 1} & Akiyama et al. [26] & $\begin{array}{l}\text { 10th grade stu- } \\
\text { dents, mean age } \\
16.6 \text { years old }\end{array}$ & In groups & Directly & No \\
\hline & Decosimo et al. [37] & $4-18$ years old & In groups & Directly & No \\
\hline & Hasanudin et al. [28] & $\begin{array}{l}\text { Information not } \\
\text { provided }\end{array}$ & In groups & Directly & No \\
\hline & $\begin{array}{l}\text { Malboeuf-Hurtubise et al. } \\
\text { [35] }\end{array}$ & $\begin{array}{l}\text { 4th to } 5 \text { th grade, } \\
\text { mean age } \\
11.3 \text { years old }\end{array}$ & In groups & Directly & No \\
\hline & $\begin{array}{l}\text { Malbouef-Hurtubise et al. } \\
\text { [34] }\end{array}$ & $\begin{array}{l}\text { Elementary } \\
\text { school students, } \\
\text { mean age } \\
8-18 \text { years old }\end{array}$ & In groups & Directly & No \\
\hline & Osofsky et al. [33] & 9 to 18 years old & In groups & Directly & No \\
\hline \multirow[t]{4}{*}{ Level 2} & Amin et al. $[27 \bullet]$ & $\begin{array}{l}7-13 \text { years old, } \\
\text { mean age of } \\
11.43 \text { years }\end{array}$ & In groups & Directly & Yes, support for parents \\
\hline & Ding and Yao [29•] & $12-18$ years old & In groups & Directly & No \\
\hline & Yuan [30] & 12 to 14 years old & Individually & Directly & No \\
\hline & Yustiana et al. [31] & $\begin{array}{l}\text { Under } 17 \text { years } \\
\text { old }\end{array}$ & In groups & Directly & $\begin{array}{l}\text { Yes, support for teach- } \\
\text { ers }\end{array}$ \\
\hline \multirow[t]{3}{*}{ Level 3} & Lee and Simpson [32] & 10 years old & Individually & Directly & Yes, support for parents \\
\hline & Stasiak et al. [38] & $\begin{array}{l}\text { Children aged } \\
7-12 \text { and ado- } \\
\text { lescents aged } \\
13-18 \text { years old }\end{array}$ & Individually & Directly & Yes, support for parents \\
\hline & Trentini et al. [36•] & $\begin{array}{l}\text { Information not } \\
\text { provided }\end{array}$ & In groups & Directly & No \\
\hline
\end{tabular}




\section{Appendix 3 Studies according to whether they reported \\ on the cost-effectiveness, accessibility and inclusion, risk management strategies, implementation and barriers of the intervention}

\begin{tabular}{|c|c|c|c|c|c|c|}
\hline Level of intervention & Reference & Cost-effectiveness & $\begin{array}{l}\text { Accessibility \& } \\
\text { inclusion }\end{array}$ & $\begin{array}{l}\text { Risk management } \\
\text { strategies }\end{array}$ & Implementation & Barriers \\
\hline \multirow[t]{6}{*}{ Level 1} & $\begin{array}{l}\text { Akiyama, Gregorio, \& } \\
\text { Kobayashi, J. [26] }\end{array}$ & No & No & No & $\begin{array}{l}\text { Yes, teachers kept } \\
\text { a record of how } \\
\text { many sessions were } \\
\text { carried out at each } \\
\text { school site }\end{array}$ & No \\
\hline & Decosimo et al. [37] & No & No & No & No & No \\
\hline & $\begin{array}{l}\text { Hasanudin, Arief, Kurnia } \\
\quad \& \text { Kusumaningrum [28] }\end{array}$ & No & No & No & No & No \\
\hline & $\begin{array}{l}\text { Malboeuf-Hurtubise et al. } \\
\text { [35] }\end{array}$ & No & No & No & $\begin{array}{l}\text { Yes, program fidel- } \\
\text { ity was assessed } \\
\text { through clinical } \\
\text { supervision }\end{array}$ & No \\
\hline & $\begin{array}{l}\text { Malbouef-Hurtubise et al. } \\
\text { [34] }\end{array}$ & No & No & No & $\begin{array}{l}\text { Yes, program fidel- } \\
\text { ity was assessed } \\
\text { through clinical } \\
\text { supervision }\end{array}$ & No \\
\hline & Osofsky et al. [33] & No & $\begin{array}{l}\text { Yes, the program } \\
\text { was developed to } \\
\text { be inclusive for } \\
\text { children who had } \\
\text { dropped out of } \\
\text { school and/or were } \\
\text { not used to leader- } \\
\text { ship roles }\end{array}$ & No & No & No \\
\hline \multirow[t]{4}{*}{ Level 2} & Amin et al. [27•] & No & $\begin{array}{l}\text { Yes, based on } \\
\text { feedback form the } \\
\text { community, the } \\
\text { intervention was } \\
\text { adapted to Urdu, } \\
\text { Punjabi and Siraiki }\end{array}$ & $\begin{array}{l}\text { Yes, based on feedback } \\
\text { from the community, } \\
\text { the intervention was } \\
\text { adapted to allow } \\
\text { regular parental con- } \\
\text { tact with deliverers }\end{array}$ & $\begin{array}{l}\text { Yes, fidelity to the } \\
\text { program was } \\
\text { evaluated through } \\
\text { clinical supervision, } \\
\text { live observation } \\
\text { and surveying co- } \\
\text { facilitators }\end{array}$ & No \\
\hline & Ding \& Yao [29•] & No & No & No & No & No \\
\hline & Yuan [30] & No & No & No & No & No \\
\hline & $\begin{array}{l}\text { Yustiana, Rusmana \& } \\
\text { Suryana [31] }\end{array}$ & No & No & No & No & No \\
\hline \multirow[t]{3}{*}{ Level 3} & Lee \& Simpson [32] & No & No & No & No & No \\
\hline & $\begin{array}{l}\text { Stasiak, Merry, Frampton } \\
\quad \& \text { Moor [38] }\end{array}$ & No & $\begin{array}{l}\text { No, two participants } \\
\text { had to be excluded } \\
\text { because they had a } \\
\text { disability }\end{array}$ & $\begin{array}{l}\text { Yes, after an initial } \\
\text { screening, potential } \\
\text { participants showing } \\
\text { moderate to severe } \\
\text { levels of depres- } \\
\text { sion or anxiety } \\
\text { were referred to an } \\
\text { appropriate treatment } \\
\text { provided by local } \\
\text { services }\end{array}$ & $\begin{array}{l}\text { Yes, research- } \\
\text { ers assessed the } \\
\text { number of sessions } \\
\text { completed by } \\
\text { children and parents } \\
\text { and asked for their } \\
\text { feedback }\end{array}$ & Yes \\
\hline & Trentini $\left[36^{\bullet}\right]$ & No & No & No & No & No \\
\hline
\end{tabular}




\section{Compliance with Ethical Standards}

Conflict of Interest Authors Jane Nursey and Sean Cowlishaw are employed by Phoenix Australia: Centre for Posttraumatic Mental Health, the organisation responsible for two resources mentioned in the introduction to this article: (1) Australian and International Guidelines for the Treatment of Acute Stress Disorder and Posttraumatic Stress Disorder, advocating a stepped care approach; (2) trialling of the SOLAR program in Australia. Lisa Gibbs also contributed to the original development of SOLAR. The remaining authors declare that they have no conflict of interest.

Human and Animal Rights and Informed Consent This article does not contain any studies with human or animal subjects performed by any of the authors.

Open Access This article is licensed under a Creative Commons Attribution 4.0 International License, which permits use, sharing, adaptation, distribution and reproduction in any medium or format, as long as you give appropriate credit to the original author(s) and the source, provide a link to the Creative Commons licence, and indicate if changes were made. The images or other third party material in this article are included in the article's Creative Commons licence, unless indicated otherwise in a credit line to the material. If material is not included in the article's Creative Commons licence and your intended use is not permitted by statutory regulation or exceeds the permitted use, you will need to obtain permission directly from the copyright holder. To view a copy of this licence, visit http://creativecommons.org/licenses/by/4.0/.

\section{References}

Papers of particular interest, published recently, have been highlighted as:

- Of importance

$\bullet$ Of major importance

1. Bonanno G, Brewin C, Kaniasty K, La Greca A. Weighing the costs of disaster: consequences, risks, and resilience in individuals, families, and communities. Psychol Sci Public Interes. 2010;11(1):1-49.

2. Beaglehole B, Mulder R, Frampton C, Boden J, Newton-Howes G, Bell C. Psychological distress and psychiatric disorder after natural disasters: systematic review and meta-analysis. 213: . Br J Psychiatry. 2018;213:716-722.

3. Peek L. Children and disasters: understanding vulnerability, developing capacities, and promoting resilience - an introduction. Child Youth Environ. 2008;18(1):1-29.

4. Norris F, Friedman M, Watson P. 60,000 disaster victims speak: part II. Summary and implications of the disaster mental health research. Psychiatry. 2002;65(3):240-60.

5. Ramos G, Scarpetta S. Combatting COVID-19's effect on children. Tackling Coronavirus (COVID-19): Contributing to a Global Effort. 2020.

6. Fore HH. A wake-up call: COVID-19 and its impact on children's health and wellbeing. Lancet. 2020;8:e861-2.

7. Phoenix Australia - centre for postraumatic mental health. Australian guidelines for the prevention and treatment of acute stress disorder, posttraumatic stress disorder and complex posttraumatic stress disorder. Melbourne. 2020.

8. Cohen GH, Tamrakar S, Lowe S, Sampson L, Ettman C, Linas B, et al. Comparison of simulated treatment and cost-effectiveness of a stepped care case-finding intervention vs usual care for posttraumatic stress disorder after a natural disaster. JAMA Psychiat. 2017;74(12):1251-8.

9. Hobfoll S, Watson P, Bell C, Bryant R, Brymer M, Friedman M, et al. Five essential elements of immediate and mid-term mass trauma intervention: empirical evidence. Psychiatry. 2007;70:283-315.

10. Brymer MJ, Taylor M, Escudero P, Jacobs A, Kronenberg M, Macy R, et al. Psychological first aid: field operations guide 2nd edition [Internet]. Los Angeles, CA; 2012. Available from: http://www.nctsn.org/content/psychological-first-aid-schoolspfa

11. Zoellner, LA, Graham, B, Bedard-Gilligan, MA. Trauma- and stressor-related disorders. In Psychopathology: Foundations for a contemporary understanding, $4^{\text {th }}$ Edition; Routledge; New York; 2016;162-81.

12. Berkowitz S, Bryant R, Brymer M, Hamblen J, Jacobs A, Layne $\mathrm{C}$, et al. National center for PTSD and national child traumatic stress Network, Skills for Psychological Recovery: Field Operations Guide. 2010.

13. O'Donnell ML, Lau W, Fredrickson J, Gibson K, Bryant RA, Bisson J, et al. An open label pilot study of a brief psychosocial intervention for disaster and trauma survivors [Internet]. Vol. 11, Frontiers in Psychiatry. 2020. p. 483. https://doi.org/10.3389/ fpsyt.2020.00483

14. Newman E, Pfefferbaum B, Kirlic N, Tett R, Nelson S, Liles B. Meta-analytic review of psychological interventions for children survivors of natural and man-made disasters. Curr Psychiatry Rep. 2014;16(9):462.

15. Brown RC, Witt A, Fegert JM, Keller F, Rassenhofer M, Plener $\mathrm{PL}$, et al. Psychosocial interventions for children and adolescents after man-made and natural disasters: a meta-analysis and systematic review. Psychological Medicine 47: Psychol Med [Internet]. 2017;47(11):1893-905. https://doi.org/10.1017/ S0033291717000496

16. Fu C, Underwood C. Meta-review of school-based disaster interventions for child and adolescent survivors. J Child Adolesc Ment Heal. 2015;27(3):161-71.

17. Rolfsnes E, Idsoe T. School-based intervention programs for PTSD symptoms: a review and meta-analysis. J Trauma Stress. 2011;224(2):155-65.

18. Shultz J, Forbes D. Psychological first aid. Disaster Heal. 2014;2(1):3-12.

19. Wang L, Norman I, Xiao T, Li Y, Leamy M. Psychological first aid training: a scoping review of its application, outcomes and implementation. Int J Environ Res Public Health. 2021;18:4594.

20. Arksey H, O'Malley L. Scoping studies: towards a methodological framework. Int J Soc Res Methodol. 2005;8(1):19-32.

21. Galvan MS, Lueke AE, Mansfield L, Smith CA. A systematic research review: how to best treat post-traumatic stress disorder in children post-natural disaster. J Hum Behav Soc Environ [Internet]. 2020; https://doi.org/10.1080/10911359.2020.18045 13

22.• Lewey JH, Smith CL, Burcham B, Saunders NL, Elfallal D, O'Toole SK. Comparing the effectiveness of EMDR and TFCBT for children and adolescents: a meta-analysis. J Child Adolesc Trauma [Internet]. 2018;11(4):457-72. https://doi.org/10. 1080/10911359.2020.1804513. This meta-analysis examined differences in effect sizes for those exposed to either single or mixed trauma.

23. Mavranezouli I, Megnin-Viggars O, Daly C, Dias S, Stockton S, Meiser-Stedman R, et al. Psychological and psychosocial treatments for children and young people with post-traumatic stress disorder: a network meta-analysis. J Child Psychol Psychiatry. 2020;61(1):18-29.

24.• Pfefferbaum B, Nitiema P, Newman B. A meta-analysis of intervention effects on depression and/or anxiety in youth exposed to political violence or natural disasters. Child Youth Care Forum 
[Internet]. 2019;48(4):449-77. https://doi.org/10.1007/s10566019-09494-9. This meta-analysis examined a range of factors that potentially influence treatment effectiveness.

25. Boldt K, Coenen M, Movsisyan A, Voss S, Rehfuess E, Kunzler $\mathrm{AM}$, et al. Interventions to ameliorate the psychosocial effects of the COVID-19 pandemic on children - a systematic review. Int J Environ Res Public Health [Internet]. 2021;18(5):1-31. https:// doi.org/10.3390/ijerph18052361.

26. Akiyama T, Gregorio ER, Kobayashi J. Youth sports activity and young people's well-being after a disaster: a trial with the Mastery Approach to Coaching (MAC) in the Philippines. BMC Res Notes. 2018;11(747):(22 October 2018).

27. Amin R, Nadeem E, Iqbal K, Asadullah MA, Hussain B. Support for students exposed to trauma (SSET) program: an approach for building resilience and social support among flood-impacted children. School Ment Health [Internet]. 2020;12(3):493-506. https://doi.org/10.1007/s12310-020-09373-y. This small randomised experimental trial of a level 2 intervention demonstrated it is possible to work with the local community to adapt the intervention to local language and context.

28. Hasanudin H, Arief YS, Kurnia ID, Kusumaningrum T. Therapeutic group can increase resilience of school-age children after the Kelud mountain disaster. EurAsian J Biosci [Internet]. 2020;14(1):2443-7.

29. Ding X, Yao J. Peer education intervention on adolescents' anxiety, depression, and sleep disorder during the COVID-19 Pandemic. Psychiatr Danub [Internet]. 2020;32(3-4):527-35. https://doi.org/10.24869/psyd.2020.527.10.24869/psyd.2020. 527. This randomised experimental trial of a level 2 intervention was one of only two seeking to promote connectedness through peer social support the other was reference 27.

30. Yuan Y. Mindfulness training on the resilience of adolescents under the COVID-19 epidemic: a latent growth curve analysis. Pers Individ Dif. 2021;172:110560.

31. Yustiana Y, Rusmana N, Suryana D. Group play therapy for the treatment of post-traumatic stress disorder in child victim of Tsunami in Banten Province. Elem Educ Online [Internet]. 2020;19(4):2140-8. https://doi.org/10.17051/ilkonline.2020.763702.

32. Lee D, Simpson S. A three-step, single session therapy intervention for COVID-related anxiety in a pediatric emergency department. Cureus. 2020;12(12):e12371.

33.• Osofsky H, Osofsky J, Hansel T, Lawrason B, Speier A. Building resilience after disasters through the youth leadership program: the importance of community and academic partnerships on youth outcomes. Prog Community Heal Partnerships Res Educ Action [Internet]. 2018;12(Special Issue):11-21. https://doi. org/10.1353/cpr.2018.0017. This quasi-experimental study, incorporating a longitudinal analysis, engaged stakeholders in shaping the intervention and included youth in disaster recovery activities.

34. Malboeuf-Hurtubise C, Léger-Goodes T, Mageau G, Joussemet M, Herba C, Chadi N, et al. Philosophy for children and mindfulness during COVID-19: results from a randomized cluster trial and impact on mental health in elementary school students. Prog Neuropsychopharmacol Biol Psychiatry [Internet]. 2021;107: 110260. https://doi.org/10.1016/j.pnpbp.2021.110260.

35. Malboeuf-Hurtubise C, Leger-Goodes T, Mageau G, Taylor G, Herba C, Chadi N, et al. Online art therapy in elementary schools during COVID-19: results from a randomized cluster pilot and feasibility study and impact on mental health. Child Adolesc Psychiatry Ment Health [Internet]. 2021;15(1):15. https://doi.org/10.1186/s13034-021-00367-5.

36. Trentini C, Lauriola M, Giuliani A, Maslovaric G, Tambelli R, Fernandez I, et al. Dealing with the aftermath of mass disasters: a field study on the application of EMDR integrative group treatment protocol with child survivors of the 2016 Italy earthquakes. Front Psychol [Internet]. 2018;4(9):862. https://doi.org/10.3389/ fpsyg.2018.00862.

37. Decosimo C, Hanson J, Quinn M, Badu P, Smith C. Playing to live: outcome evaluation of a community-based psychosocial expressive arts program for children during the Liberian Ebola epidemic. Glob Ment Heal [Internet]. 2019;6: e3. https://doi.org/ 10.1017/gmh.2019.1.

38. Stasiak K, Merry S, Frampton C, Moor S. Delivering solid treatments on shaky ground: feasibility study of an online therapy for child anxiety in the aftermath of a natural disaster. Psychother Res [Internet]. 2018;28(4):643-53. https://doi.org/10.1017/gmh.2019.1.

39. Gibbs L, Snowdon E, Block K, Gallagher HC, MacDougall C, Ireton $\mathrm{G}$, et al. Where do we start? A proposed post disaster intervention framework for children and young people. Pastor Care Educ. 2014;32(1):68-87. https://doi.org/10.1080/02643944.2014.881908

40. IPCC. Global Warming of $1.5^{\circ} \mathrm{C}$. An IPCC special report on the impacts of global warming of $1.5^{\circ} \mathrm{C}$ above pre-industrial levels and related global greenhouse gas emission pathways, in the context of strengthening the global response to the threat of climate change. In press; 2018.

41. United Nations. Sendai framework for disaster risk reduction 20152030 [Internet]. Sendai, Japan; 2015. Available from: https://www. preventionweb.net/files/43291_sendaiframeworkfordrren.pdf

Publisher's Note Springer Nature remains neutral with regard to jurisdictional claims in published maps and institutional affiliations. 